DOI: 10.17707/AgricultForest.62.1.30

\author{
Dane BOSHEV, Mirjana JANKULOVSKA, \\ Vjekoslav TANASKOVIK, Sonja IVANOVSKA, \\ Velibor SPALEVIC, Darko KARAKOLEVSKI ${ }^{1}$
}

\title{
ASSESSMENT OF YIELD AND QUALITY OF SPRING BARLEY DEPENDING OF FOLIAR FERTILIZATION
}

\begin{abstract}
SUMMARY
Barley is the fourth most important cereal in the world, right behind maize, wheat and rice, but before sorghum, oat and rye. In Republic of Macedonia, barley is sown on a quarter of the entire cereal production area. On the National variety list, there is only one registered variety of spring barley -Makedo. Barley grain yield can vary from year to year. It is highly dependent on of the climate conditions, as well as the agronomic measures applied during the vegetation period. One of the most important measures is the fertilization of the crops.

Starting from the fact that the use of chelate fertilizer solutions, using the spray-on foliar method is in the early development phase, an experiment was conducted using spring barley Makedo variety, and three types of chelate fertilizer solutions (Agrosal N12P5K7+ME, Agrosal NH4NO3 50\% and Agrosal $\mathrm{N} 31 \mathrm{P} 0 \mathrm{~K} 0+\mathrm{ME})$, applied in 6 different concentrations $(0.5,1,3,5,10$ and 15 percent).

The average grain yield was $1347 \mathrm{kgha}-1$, the best results of this trait were registered at the crops treated with Agrosal N12P5K $7+\mathrm{ME}$ in a 1 percent solution, while the lowest yield was measured on the crops treated with Agrosal $\mathrm{N} 31 \mathrm{P} 0 \mathrm{~K} 0+\mathrm{ME}$ in the concentration of 0.5 percent. The quality highly varied depending of the different applied treatments. Highest protein content was registered on the crops treated with Agrosal N31P0K0+ME in a 10 percent solution, whilst the lowest on the crops treated with Agrosal N12P5K7+ME, in a 0.5 percent solution.
\end{abstract}

Keywords: spring barley, foliar fertilizer, yield, quality

\section{INTRODUCTION}

Barley is the fourth most significant cereal in the world, right after corn, wheat and rice (FAO, 2013). Barley accounts for around 41000 ha, of the total production of cereals in the Republic of Macedonia (State Statistical Office of the Republic of Macedonia, 2014). The majority parts of the varieties are imported

\footnotetext{
${ }^{1}$ Dane Boshev (corresponding author: dbosev@yahoo.com), Mirjana Jankulovska, Vjekoslav Tanaskovik, Sonja Ivanovska, University Ss Cyril and Methodius, Faculty of Agricultural Sciences and Food, Skopje, REPUBLIC OF MACEDONIA; Velibor Spalevic, Institute of Forestry, Podgorica, MONTENEGRO; Darko Karakolevski, Philip Morris Tutunski Kombinat, Prilep, REPUBLIC OF MACEDONIA

Notes: The authors declare that they have no conflicts of interest. Authorship Form signed online.
} 
autumn varieties. On the National variety list in Republic of Macedonia is registered the two rows spring barley - variety Makedo as the only domestic variety (MAFWE, 2008).

The efficient cereal production, including barley, largely depends on the applied agro-technics, especially the diet. Numerous tests have been performed, which confirmed that proper and balanced cereals diet is essential to improve the yield and quality and can directly and indirectly affect the efficiency of the other agro-technical measures (Negrilã and Negrilã, 1995; Popescu et al., 1997). Basic nutrients, such as nitrogen, phosphorus, potassium, sulfur and magnesium, are crucial elements in many processes in the development of the plant and the formation of the yield (Randahwa and Arora, 2000), but besides these elements, microelements play a large role in the quality of final product as well.

Common practice in cereal production is introduction of nutrients through the soil. However, recently it has been discovered that different nutritive solutions containing the elements, enable easy availability of nutrients to plants, which results in positive outcomes (Alaru et al., 2003; Arif et al., 2006). Because of the fact that soil application of nutrient solutions can lead to loss of nutrients (Dines et al., 2002; Follet and Delgado, 2002), over the last decades it has been confirmed for the fact that foliar application is the preferred option and it can reduce losses (Brar and Brar, 2004; Kinaci and Kinaci, 2001; Cakmak, 2008; Babaeian et al., 2011). Fast and efficient input of required elements into the plants, in the form of nutrient solutions is commonly performed through the leaf. This method has higher efficiency and lower cost and at the same time, it does not pollute the environment (Abbou El-Nour, 2002; Bozogi et al., 2011).

Foliar fertilization, i.e. supplementation of nutrients through the leaf, represents an efficient fertilization technique which highlights the availability of nutrients. In more developed countries, this application is simplified through a large-scale sprinkling irrigation (linear machines, ranger machines, hydromatics etc.), a process known as fertigation, or simultaneous irrigation and feeding. In this context, Tanaskovik and Chukaliev (2014) point out that in the United States fertigation of agricultural crops (corn, soybeans, etc.) is conducted via sprinkling irrigation systems, where instead of conventional sprinklers, micro-sprinklers are set near the surface. Quite often, besides fertigation, pesticides are applied via this system, a process known as chemigation. Unfortunately, due to the separation of production area on small plots, such a technique where really big irrigation systems can efficiently and economically operate is not applicable in our country.

Awasti and Brahm (1994) conclude that the barley yield is increased by increasing the dose of nitrogen. In addition to this element, a number of studies so far have proven the usefulness of treating cereals with nutrient solutions containing other important elements (Diaz-Zorita et al., 2001; Kinaci and Kinaci, 2001; Demirer et al., 2004), whereby the yield and the quality are enhanced with positive effects. 
Foliar application of nitrogen at different development stages of wheat and triticale development improve seed quality and increase yield (Brar and Brar, 2004; Saeed et al., 2012). Well balanced nitrogen and phosphorus fertilization increases the nitrogen content of the wheat grain, but also affects the gluten formation (Hera et al., 1996; Brucher and Moroy, 1988).

Nitrogen deficiency, which occurs due to constant dynamics of this element in the soil, can cause poor growth and poor plants vitality, yellowing of leaves, formation of tiny leaves, falling leaves, forming a less branched root system, small and poor quality fruits etc. The nitrogen supply of the crop is one of the essential measures for successful and quality agricultural production.

From the farmers' perspective, it is difficult to achieve high yields and high protein content in grain at the same time, because these properties are usually inversely proportional. Bhatia and Rabson (1976) and Sinclair and DeWitt (1995) have shown that the simultaneous increase in yield and protein content was incompatible in terms of energy. For best growth and development of plants, specific amounts of certain nutrients at certain times are required (Sajid et al., 2008).

The research results of Bosev et al. (2013) showed that different treatments with nutritive solutions have significant effects on wheat and triticale. Applications of different concentrations of nutritive solutions have shown increased protein synthesis and content of wet gluten in wheat and triticale (Bosev et al., 2012). Other researchers also point out that foliar application of nutrient solutions has positive impact on the yield of wheat grain (Yassen et al., 2010; Matilo et al., 2006; Slaton et al., 2011). Römheld and El-Fouly (1999) came to the conclusion that the effectiveness of foliar application is better than that of soil application of nutrient solutions, because in this way, the intake of necessary nutrients is focused directly at the site where it is needed most - in the leaf, and has relatively rapid absorption.

In Macedonia, there is data deficiency regarding the effects of the use of nutritive solutions in barley. Considering the fact that in Macedonia the use of nutritive solutions in cereals is in nascent, while in other crops has seen rapid rise, the aim of this research was to determine the effects of different nutritive solutions at different concentrations on grain yield and protein content in brewing barley. Through the results of this research it will be able to see the influence of different concentrations of nutritive solutions, applied at different stages of plant development, on the analyzed traits. Determination of the necessary dosages and the type of solution required for obtaining higher yields and adequate quality of barley will result in lowering the cost of fertilization, which will further lead to a reduction of the production costs of brewing barley. Such measures can ultimately lead to the spread of the areas sown with brewing barley in Macedonia.

\section{MATERIAL AND METHODS}

The experiments of this research were conducted in the Skopje region (41 $56^{\circ} 58^{\prime \prime N}$ and $21^{\circ} 25^{\prime} 06^{\prime \prime E}, 550 \mathrm{~m}$ above sea level), with the two rows brewing 
barley, variety Makedo. The experiment was designed as CRBD, with three fertilizers and six concentrations, in three replications. The blocks represent the nutritive solution, which are marked with the letters $\mathrm{A}, \mathrm{B}$ and $\mathrm{C}$, and refer to the following nutritive solutions:

Agrosal N12P5K7+ME (A)- liquid mineral fertilizer which, in addition to basic nutritive elements, contains microbiogenetic elements in chelated form (Table 1).

Table 1. Chemical content of Agrosal $\mathrm{N}_{12} \mathrm{P}_{5} \mathrm{~K}_{7}+\mathrm{ME}(\%)$

\begin{tabular}{|c|c|}
\hline Total Nitrogen $\left(\mathrm{N}_{2}\right)$ & $12.00 \pm 0.7 \%$ \\
\hline Phosphorus $\left(\mathrm{P}_{2} \mathrm{O}_{5}\right)$ & $5.00 \pm 0.7 \%$ \\
\hline Potassium $\left(\mathrm{K}_{2} \mathrm{O}\right)$ & $7.00 \pm 0.7 \%$ \\
\hline \multicolumn{2}{|c|}{ Microelements in chelated form: $\mathrm{Mg}, \mathrm{Cu}, \mathrm{Zn}, \mathrm{Mn}, \mathrm{Ca}, \mathrm{Co}, \mathrm{Fe}, \mathrm{B}$} \\
\hline
\end{tabular}

Agrosal NH4NO350\% (B)- liquid nitrogen fertilizer where nitrogen is in ammonia and nitrate form (Table 2).

Table 2. Chemical content ofAgrosal $\mathrm{NH}_{4} \mathrm{NO}_{3} 50 \%(\%)$

\begin{tabular}{|c|c|}
\hline Ammonia Nitrate $\left(\mathrm{NH}_{4} \mathrm{NO}_{3}\right)$ & $48.00 \%-52.00 \%$ \\
\hline Total Nitrogen $\left(\mathrm{N}_{2}\right)$ & $16.80 \%-18.20 \%$ \\
\hline
\end{tabular}

Agrosal $\mathrm{N}_{31} \mathrm{P}_{0} \mathrm{~K}_{0}+\mathrm{ME}(\mathrm{C})$ - liquid nitrogen fertilizer, in which nitrogen is found in all three forms (ammonia, nitrate and amide), and contains iron and magnesium (Table 3).

Table 3. Chemical content of Agrosal $\mathrm{N}_{31} \mathrm{P}_{0} \mathrm{~K}_{0}+\mathrm{ME}(\%)$

\begin{tabular}{|c|c|}
\hline Total Nitrogen $\left(\mathrm{N}_{2}\right)$ & $31.00 \pm 1.5 \%$ \\
\hline Ammonia nitrate $\left(\mathrm{NH}_{4} \mathrm{NO}_{3}\right)$ & $37.00 \pm 2.0 \%$ \\
\hline \multicolumn{2}{|c|}{ Microelements in chelated form: $\mathrm{Mg}, \mathrm{Fe}$} \\
\hline
\end{tabular}

The variants of the concentrations used in the study are marked with numbers 1 to 6 and refer to the following concentrations of the solution: $0.5 \%$ (1) $1 \%$ (2) $3 \%$ (3) $5 \%$ (4) $10 \%$ (5) and $15 \%$ (6).

Prior to setting up the experiment, in order to determine the application irrigation rate with the nutrient solution, an agro-chemical analysis of the soil was done, and retention of moisture and bulk density were determined. The plots were $5 \mathrm{~m} 2$ each, and each plot had 8 rows positioned at a distance of $12.5 \mathrm{~cm}$. During the vegetation, the plots were kept clean of weeds. The treatment with nutrient solution was done manually, in the following phases of plant growth: tillering, stem extension, head visible and early maturity of the grain. During the harvest, all plants were harvested from the plots in order to determine the yield of grains (kg ha-1) and the protein content (\%).

The analysis of the yield of grain results was calculated to $14 \%$ moisture, and the protein content was determined by the method of khjeldal. The results were statistically processed by the method of analysis of variance (ANOVA), and 
mean values for the properties in respect of all the factors involved in the survey were analyzed by LSD-test.

\section{Anlysis of variance}

\section{RESULTS AND DISCUSSION}

In order to determine the effect of the factors (nutritive solution and concentration) as well as their interactive impact on analyzed characteristics, an analysis of variance - ANOVA was conducted. This analysis provides insight into the impact on individual examined traits, as well as the interaction influence of the factors on their performance.

Table 4. Influence of the source of variability on the analyzed traits

\begin{tabular}{|l|c|c|c|c|c|}
\hline $\begin{array}{l}\text { Source of } \\
\text { variation }\end{array}$ & Replication & Fertilizer & Concentration & Interaction & Error \\
\hline Df & 2 & 2 & 5 & 10 & 34 \\
\hline Yield & $37742 \mathrm{~ns}$ & $267350^{* *}$ & $210108.6^{* *}$ & $316168^{* *}$ & 21220.7 \\
\hline Proteins & $0.099 \mathrm{~ns}$ & $10.861^{* *}$ & $2.415^{* *}$ & $5.999^{* *}$ & 0.114 \\
\hline
\end{tabular}

Based on the obtained values (Table 4), it can be concluded that the fertilizer concentration had a very significant impact on the tested properties, meaning that it is crucial for their expression. Nutrient solution showed highly significant influence on both yield and quality. The interaction of the concentration with the nutrient solution had higly significant effect on the tested properties, which confirms the fact that apart from the right choice of the nutrient solution, it is crucial to determine the concentration of the same. These two factors together are the key to getting good results in brewing barley cultivation.

\section{Grain yield}

Barley grain is the main product and the main reason for growing barley as well, except when used in silage, or as biomass for biogas production, when the whole plant is being used. The yield is limited by the genetic potential of the plant itself, but it largely depends on the technical measures applied to the crop. So far, there are numerous surveys confirming the link between foliar application of nutritive solutions and yield. Thus, Shah and Saeed (1989) came to the conclusion that the barley grain yield has increased by foliar application of nitrogen solutions and Fathi et al. (1990) and Szafranski (1995) concluded that this characteristic is directly related to the dosage of nitrogen applied.

The results of our study are shown in Table 5. In terms of the interaction of the two factors in the experiment, the highest grain yield was seen at A2 $(2355 \mathrm{~kg}$ $\left.\mathrm{ha}^{-1}\right)$, while the lowest in $\mathrm{C} 1\left(988 \mathrm{~kg} \mathrm{ha}^{-1}\right)$. Statistically, these values were significantly different in comparison to all other combinations of nutritive solution and concentration.

If the effect of the concentration in the blocks is analyzed in details, in block A, the highest value was achieved with the plants treated with two concentrations (2355 $\left.\mathrm{kg} \mathrm{ha}^{-1}\right)$, and the lowest using concentration $4(1047 \mathrm{~kg} \mathrm{ha}$ 
$\left.{ }^{1}\right)$. Blocks treated with solutions B and C obtained similar results with each other, that is, the highest yields were observed in treatment 4 , and the lowest in treatment 2.

Table 5. Grain yield $\left(\mathrm{kgha}^{-1}\right)$

\begin{tabular}{|c|r|r|r|r|r|r|r|}
\hline & \multicolumn{1}{|c|}{1} & 2 & 3 & 4 & 5 & 6 & Average \\
\hline A & 1444 & 2355 & 1221 & 1047 & 1342 & 1244 & 1442 \\
\hline B & 1104 & 1269 & 1146 & 1318 & 1260 & 1163 & 1210 \\
\hline C & 988 & 1284 & 1592 & 1643 & 1383 & 1454 & 1391 \\
\hline Average & 1179 & 1636 & 1320 & 1336 & 1328 & 1287 & 1348 \\
\hline
\end{tabular}

Fertilizer $\mathrm{LSD}_{0.05}=82$ Concentration $\mathrm{LSD}_{0.05}=56$ Interaction $\mathrm{LSD}_{0.05}=51$

Fertilizer $\mathrm{LSD}_{0.01}=195$ Concentration $\mathrm{LSD}_{0.01}=94$ Interaction $\mathrm{LSD}_{0.01}=77$

In terms of the impact of the concentration of the solutions, the average values of the yield of grain indicate that the highest value of grain yield $(1636 \mathrm{~kg}$ $\mathrm{ha}^{-1}$ ) was observed in treatment 2 , while the lowest has been reported in treatment $1\left(1179 \mathrm{~kg} \mathrm{ha}^{-1}\right)$. The differences are statistically significant compared to other applied concentrations. The highest average yield was obtained in the block treated with the fertilizer A (1442 kg ha $\left.{ }^{-1}\right)$, followed by the fertilizer C $(1391 \mathrm{~kg}$ $\left.\mathrm{ha}^{-1}\right)$. The lowest yield was achieved in the block treated with B $\left(1210 \mathrm{~kg} \mathrm{ha}^{-1}\right)$, statistically significantly lower yield compared with other fertilizers. Mean values for blocks have confirmed the importance of balanced diet, i.e. the participation of all elements, as well as the justification of the application of foliar nutrient solutions. Namely, the use of relatively low concentrations resulted in higher yields. Additionally, the use of multiple components nutrient solutions (NPK), required lower concentrations of the solution compared to the solutions dominated by nitrogen.

\section{Protein content}

The protein content is one of the important features of the cereals, which is an indicator of their quality. Two rows brewing barley, compared to wheat and other cereals used in bakers' industry, differs in a way that with it, this property is coveted to have as lower values as possible, if used in brewing industry. The reason for this is because the protein can cause biochemical instability of the brewing, which usually manifests as foggy brewing (Beer Haze), what means clouding of beer caused by proteins breakdown.

The results obtained by Jasvinder (2012) in the experiments with different $\mathrm{N}_{2}$ doses on the two rows brewing barley, show that the protein content was proportional to the amount of nitrogen applied. Similar results have been obtained by Tarjoc and Tabara (2011) in the tests they had performed on brewing barley with foliar application of different nutritive solutions.

From the results presented in Table 6, it can be concluded that the highest protein content in terms of interaction effect of the two factors was obtained in treatment C5 (12.91\%), while the lowest in treatment A5 (8.07\%), which is in 
line with the previous investigations conducted by several authors. Statistically these results are significantly different from the other set for this parameter.

Table 6. Protein content (\%)

\begin{tabular}{|c|r|r|r|r|r|r|r|}
\hline & \multicolumn{1}{|c|}{1} & \multicolumn{1}{|c|}{2} & \multicolumn{1}{|c|}{3} & \multicolumn{1}{c|}{4} & \multicolumn{1}{c|}{5} & \multicolumn{1}{c|}{6} & Average \\
\hline A & 8.82 & 9.55 & 12.26 & 8.95 & 8.07 & 10.57 & 9.71 \\
\hline B & 10.61 & 11.31 & 9.91 & 11.73 & 11.86 & 11.06 & 11.08 \\
\hline C & 10.93 & 8.96 & 11.79 & 11.63 & 12.91 & 9.89 & 11.02 \\
\hline Average & 10.12 & 9.94 & 11.32 & 10.77 & 10.95 & 10.51 & 10.60 \\
\hline
\end{tabular}

Fertilizer $\mathrm{LSD}_{0.05}=0.19$ Concentration $\mathrm{LSD}_{0.05}=0.13$ Interaction $\mathrm{LSD}_{0.05}=0.13$

Fertilizer $\mathrm{LSD}_{0.01}=0.45$ Concentration $\mathrm{LSD}_{0.01}=0.22$ Interaction $\mathrm{LSD}_{0.01}=0.18$

If we analyze each block separately, in order to recognize the influence of the concentration in a particular block, we can say that, in block A, the highest percentage of protein showed plants in treatment $3(12.26 \%)$ and the lowest in treatment $5(8.07 \%)$. In block B, the highest results were obtained with the dose 5 (11.86\%), as opposed compared to the results obtained in the previous block. Similar values have been achieved with dosage $4(11.73 \%)$, so that statistically non significant differences were found between these values. The plants treated with the dose $3(9.91 \%)$, had the lowest content of protein. In block C, the highest values were measured in plants treated with nutritive solution concentration $5(12.91 \%)$ and the lowest in plants with a dose $2(8.96 \%)$. These results support the claim that protein synthesis is closely dependant on the amount of nitrogen applied on plants.

From the perspective of the influence of nutrient solutions on average values of protein content, the highest share of protein was measured in the block B (11.08\%). Similar results were found in block C (11.02\%), and the lowest in block A $(9.71 \%)$, which is the only one that showed a statistically significant difference compared to blocks B and C. In terms of the effect of concentration, the highest average values had dose $3(11.32 \%)$, which significantly differed from other concentrations, and the lowest values were obtained in dose 2 $(9.94 \%)$. The remaining doses showed similar values ranging from $10.12 \%$ to $10.95 \%$.

\section{CONCLUSIONS}

From the results of the tests conducted on the Makedo two-rows brewing barley, one may perceive which nutritive solutions and in what way they affect the analyzed properties, if applied foliar at different concentrations. The highest yield of grain is determined in plants treated with $1 \%$ solution of Agrosal $\mathrm{N}_{12} \mathrm{P}_{5} \mathrm{~K}_{7}+\mathrm{ME}$, and the highest yield in terms of the impact of nutrient solution showed the plants treated with Agrosal $\mathrm{N}_{12} \mathrm{P}_{5} \mathrm{~K}_{7}+\mathrm{ME}$. The highest concentration of protein is observed in the plants treated with $10 \%$ solution of Agrosal $\mathrm{N}_{31} \mathrm{P}_{0} \mathrm{~K}_{0}+\mathrm{ME}$, and the lowest in the plants treated with $10 \%$ solution of Agrosal $\mathrm{N}_{12} \mathrm{P}_{5} \mathrm{~K}_{7}+\mathrm{ME}$. 
If barley is grown in order to be used in the brewing industry, then the most appropriate treatment is with Agrosal $\mathrm{N}_{12} \mathrm{P}_{5} \mathrm{~K}_{7}+$ MEin $10 \%$ solution concentration, because this combination of nutrient solution and dosage results in low protein content. If the purpose of cultivation is the use of this crop as fodder, in that case Agrosal $\mathrm{N}_{31} \mathrm{P}_{0} \mathrm{~K}_{0}+\mathrm{ME}$ and concentration of $10 \%$ solution is recommended, because this treatment provides plants whose grains have the highest proportion of protein.

On the other hand, treatment with Agrosal $\mathrm{N}_{12} \mathrm{P}_{5} \mathrm{~K}_{7}+\mathrm{ME}$ at a dose of $1 \%$, showed the highest yields and acceptable low percentage of protein, which would be a good combination for brewing industry production of as well as for fodder.

\section{REFERENCES}

Abou, El-Nour E.A.A. (2002): Can supplemented potassium foliar feeding reduce the recommended soil potassium? - Pakistan Journal of Biological Science, 5(3):259-262.

Alaru, M., Laur, Ü. \& Jaama, E. (2003): Influence of nitrogen and weather conditions on the grain quality of winter triticale. Agron, Res 1:3-10

Arif, M., Chohan, M.A., Ali, S., Gul, R. \& Khan, S. (2006). Response of wheat to foliar application of nutrients. Journal of Agricultural And Biological Science 1, 30-34.

Awasti, U.D. \& Brahm, S. (1994): Physiological response of barley genotipes to nitrogen levels under moisture scarce conditions on light extrude soils of Central Utter Pardash. Indian Journal of Plant Physiology, 37:32-34.

Babaeian, M., Tavassoli, A., Ghanbari, A., Esmaeilian, Y. \& Fahimifard, M. (2011): Effects of foliar micronutrient application on osmotic adjustments, grain yield and yield components in sunflower (Alstar cultivar) under water stress at three stages. Afr J Agric Res., 6(5):1204-1208.

Bhatia, C.R. \& Rabson, R. (1976): Bioenergetic considerations in cereal breeding for protein improvement. - Sciece, 194 (4272):1418-21.

Bosev, D., Ivanovska, S., Jankulovska, M., Jankuloski, Lj.\& Kuzmanovska, B. (2013):Influence of foliar fertilization on agromorphological traits of wheat and triticale. InternationalSymposiumforAgricultureandFood (12-14 Dec), Symposium Proceedings, pg. 33-38. Skopje, Republic of Macedonia.

Bosev, D., Ivanovska, S., Jankulovska, M., Jankuloski, Lj., Kuzmanovska, B.\&Yanchev, I. (2012): Improving the yield and quality of wheat and triticale by foliar fertilization. Agricultural Sciences, Vol. IV, Issue 11, pg. 19-22, Plovdiv, Bulgaria.

Bozogi, H.A, Azarpour, E. \& Moradi, M. (2011): The effects of bio, mineral nitrogen fertilization and foliar zinc spraying on yield and yield components of faba bean. $-\mathbf{J}$ World Appl. Sci., 13(6):1409-1414.

Brar, M.S. \& Brar, A.S. (2004): Foliar nutrition as a supplement to soil fertilizer application to increase yield of upland cotton (Gossypium hirsutum). -Indian J. Agric. Sci., 74:472-475.

Brucher, P.L \& Moroy, D.D. (1988): Nitrogen effencts on soft red winter wheat yield agronomic characteristics and quality. - Crop science, 28:152-157

Cakmak, I. (2008). Enrichment of cereal grains with zinc: Agronomic or genetic biofortification - Plant Soil., 302:1-17.

Demirer, T., Ozer, I., Koctuk, O.M. \& Er, A.Y. (2004): Effects of different leaf fertilizers on yield and quality in sunflower (Hellanthus annuus L.) - Pakistan J. Biol. Sci., 7:384-388. 
Diaz-Zorita, M., Fernandez-Canigia, M.V. \& Grosso, G.A. (2001): Applications of foliar fertilizers containing glicinebetaine impove wheat yields. - J.Agron. - Crop Sci., 196:209-215.

Dinnes, D.L, Karlen, D.L., Jaynes, D.B, Kaspar, T.C., Hatfield, J.L., Colvin, T.S \& Gambardella, C.A (2002): Nitrogen management strategies to reduce nitrate leaching in tile-drained Midwestern soils. Agronomy Journal, 94:153-171.

FAO (2013): World crop production. Published online ahttp://www.faostat.fao.org

Fathi, A.O., Abdel, A. \& Gawish, S.M. (1990): Effect of Foliar Application of some micronutrients under different levels of $\mathrm{N}$ fertilization on yield and nutrient content of wheat plant. Annals of Agricultural Sciences. Moshthotor- 28:2669-2680.

Follett, R.F.\& Delgado, J.A. (2002): Nitrogen fate and transport in agricultural systems. J. Soil Water Conserve, 57.

Hera, C., Indriceanu, A., Mihaila, V., Popescu, S., Chardas, G. \& Vassiliki, P. (1986): Ifluensa fertilizari asupra unor indici calitativi ai recltei de grau. - Probl. Agr.Teor aplic., vol. VIII, nr.2:161.

Jasvinder, S., Mahal, S.S.\& Manahas, S.S. (2012): Effect of Agronomic practices on Growth, Grain Yield, Malt yield losses of Barley( Hordeum vulgare L.) - Journal of Agricultural Physics, vol.12, N01, 3-8.

Kinaci, G. \& Kinaci, E. (2001): Effects of various foliar fertilizers on yield and quality characteristics of wheat. - S.U.J. Agriculture Fac., 15:115-123.

MAFWE (2008):National variety list of Republic of Macedonia. RI Grafica, Skopje, Republic of Macedonia.

Matilo, A., Hassan Z.U., Shah A.N. \& Khan, H. (2006): Growth, yield and nutrient uptake of wheat (Triticum aestivum L.) in relation to foliar and soil application of urea. - Int. J. Agri. Biol., 8 (4):477-481.

Negrilã, M. \& Negrilã, E. (1995): Acpiunea ingrã amintelor cu azot i fosfor usupra producpiei - An I.C.C.P.T Fundulea, vol. LXIV, 117.

Popescu, S. Idriceanu, A., Stan, S., Mihãilã, V., Negrilã, M., Povarnã, F.I \& Ionescu, Fl. (1997): Implicapii ale dezechilibrelor nutritive in sintenza proteinei la grau. An. I.C.C.P.T Fundulea.

Randahwa, P.S. \& Arora, C.L. (2000): P and S interaction effect on dry matter yield and nutrient uptake by wheat. Journal of indian society of soil science. 48(3):536-540.

Römheld, V. \& El-Fouly, M.M. (1999): Foliar nutrient application - Chalenge and limits.

Saeed, B., Gul, H., Khan, A.Z. \& Parveen, L. (2012): Growth Factors and Straw Yield of Wheat Cultivars in Relation with Nitrogen and Sulfur Fertilization. APRN journal of Agricultural and Biological Science 7 (1).

Sajid, A., Khan, A.R, Mairaj, G., Fida, M. \& Bibi, S. (2008): Assesment of different crop nutrient management practises of yield improvement. - Australian Journal of Crop Sciences.

Shah, K.H. \& M. Saeed, (1989): Effect of combinaton of soil and foliar application of urea on three wheat genotypes, Pak. J. Scient and Industr. Res., 32:813-815.

Sinclair, R. \& De Witt, C.T (1995): Photosynthate and nitrogen requrement for seed production by various crops. - Science, 189.

Slaton, N.A., Norman, R.J., \& Kelley, J. (2011): Winter wheat yield response to a urea amended with a urease inhibitor and fertilization time. Online. Crop Management. Doi:10. 1094.Cm-2011-0126-01-RS.

State Statisctical Office of The Republic of Macedonia (2012): Statistical review: Agriculture, Page 20, Table 5. Skopje, Republic of Macedonia. 
Szafranski. W., (1995): The effect of the level and method of nitrogen fertilizer application on grain yield of selected cultivars of barley and oats depending on the environmental conditions of the foothills of the Carpathians: Harvest index and the level of grain yield. ZesvtvNaukoweAkademilRolniczejimHungonaKollataja W Krakowie. Rolctwo No. 32:99-111.

Tanaskovik, V. \& Chukaliev, O. (2014):Fertirrigation. Internal lectures script. University Ss Cyril and Methodius, Faculty of Agricultural Sciences and Food - Skopje, Skopje, Republic of Macedonia.

Tarjoc, F.C. \& Tabara, V (2011): Issues concerning the impact of foliar fertilization on the production of barley in Timisoara. Research Journal of Agricultural Science, 43 (I), 2011, 186:189.

Yassen, A., Abou El-Nour, E.A.A \& Shedeed, S. (2010): Response of wheat to foliar spray with urea and micronutrients. - Journal of American Science, 6 (9): 1422.Xi K, Morrall RAA, Baker RJ and Verma PR. 1990. Relationship between incidence and severity of blackleg disease of rapeseed. Canadian Journal of Plant Pathology, 12:164-169.

Yürüt HA, Erkal Ü, and Gürer M. 1994. Hazelnut Diseases in Bolu, Düzce and Bartın. 9th Congress of the Mediterranean Phytopathological Union, Kuşadası, Aydın, Türkiye: Turkish Phytopathological Society Publications No: 7, pp. 417-419. 